\title{
State Aid
}

GEORGE PERETZ QC

\subsection{Introduction}

The EU state aid rules date from the very earliest development of what was to become the European Union: predecessor provisions were to be found in the Treaty establishing the European Coal and Steel Community (1951), ${ }^{1}$ and the provisions in the Treaty on the Functioning of the European Union (TFEU) are substantially unchanged from the Treaty of Rome (1957). ${ }^{2}$ They have been regarded from the outset as foundational provisions: the fundamental aim of reducing barriers to trade between member states would produce politically unacceptable results if the reduction of barriers to trade exposed domestic producers in one state to the risk of being undercut by subsidized imports from another state. Since European states have tended to spend a relatively high proportion of national income, and to intervene relatively extensively in the economy, the risk of distortive subsidies of that kind has always been high.

The EU state aid rules have the following important features. The concept of 'state aid' is defined widely to include all forms of public financing, including reduced charges, guarantees or loans at favourable rates, tax waivers, many exemptions from tax as well as classic handouts of cash. The European Commission has wide powers to declare aid to be permitted (or 'compatible with the internal market') on broad public policy grounds set out in Article 107(2) and (3) TFEU. Critically, Article 108(3) TFEU prohibits member states from implementing any measure that amounts to state aid unless and until it has been notified to, and cleared by, the Commission: and aid implemented in breach of that rule is unlawful, with both the Commission and national courts having the

1 Treaty establishing the European Coal and Steel Community (1951), Arts 4, 54 and 95.

2 Treaty establishing the European Economic Community (1957), Arts 87-89. 
power to order repayment of any such aid and (in the case of a national court) damages to third parties affected by the unlawful aid.

That structure gives the Commission a powerful role at the heart of the regime: it is the arbiter (subject only to judicial review by the EU courts) of what state aid is permissible. State aid not approved by it is unlawful, and it is able to order member states to recover unlawful aid, subject only to the possibility of judicial review by the General Court and the Court of Justice of the European Union (CJEU).

The severity of that regime is tempered by 'block exemptions' (regulations that define certain categories of aid that is automatically regarded as cleared without being notified), but the drafting of those regulations is under the Commission's control.

\subsection{Background to Protocol Article 10}

Against that background, it was inevitable that the EU's agreement to, in effect, barrier-free trade in goods between Northern Ireland and the EU would be conditional on the application of strict subsidy control rules to measures that could affect that trade. Absent such rules, it would have been possible for subsidized goods circulating in Northern Ireland to enter the EU across the legally and physically undefended Ireland-Northern Ireland border. Member states subject to the disciplines of the state aid rules were never going to accept that there could be territory effectively within the EU internal market that was not subject to those rules.

Accordingly, in the draft Withdrawal Agreement (WA) negotiated in November 2018 under the government of Prime Minister May, the draft Protocol contained, first, at Article 12, a provision in the same terms as what is now Article $10 .^{3}$ For the May government, that provision was unproblematic because it had by that stage essentially decided that EU state aid rules would in any event continue to apply to the whole of the UK after Brexit; indeed, Part 4 of Annex 4 to that draft Protocol contained provisions applying to GB that would, absent other arrangements agreed before the end of the transitional period, have extended the EU state aid rules to GB, though with a UK independent authority taking the role played by the Commission in the EU, subject to various forms of oversight by the Commission. ${ }^{4}$

${ }^{3}$ https://ec.europa.eu/info/sites/default/files/draft_withdrawal_agreement_0.pdf.

${ }^{4}$ For an analysis of those provisions, see G Peretz, 'State Aid and the Withdrawal Agreement: Key Points' (3 December 2018), https://uksala.org/state-aid-and-thewithdrawal-agreement-key-points/. 
As discussed previously, ${ }^{5}$ the government of Prime Minister Johnson that took office in July 2019 reverted to the 'Northern Ireland only' arrangements that had originally been the EU's suggested approach to the problems posed by Brexit in the island of Ireland and included in its initial public draft of February $2018 .^{6}$ It was also clear - in state aid as elsewhere - that the UK government would not commit in a withdrawal agreement to remain under any obligations to align to EU rules, outside Northern Ireland. The EU's insistence on maintaining what was previously Article 12 as what is now Article 10 was therefore unsurprising. What was surprising was that the Johnson government accepted the retention of that Article without, it appears, appreciating its implications for the UK as a whole.

\subsection{Terms of Article 10}

Like much of the Protocol, Article 10(1) does not offer a lazy reader ${ }^{7}$ much clue as to its meaning or purpose. It provides: 'The provisions of Union law listed in Annex 5 to this Protocol shall apply to the United Kingdom, ... in respect of measures which affect that trade between Northern Ireland and the Union which is subject to this Protocol.' It is only when the diligent reader turns to Annex 5 that she can begin to understand what this provision is about. Annex 5 contains the whole corpus of EU state aid law, starting with the TFEU provisions and then running through EU secondary legislation (procedural rules and block exemptions) as well as 'soft legislation' such as Commission communications and guidance on the meaning of key concepts of state aid law and as to its policy approach to the exercise of its powers under the state aid rules.

When the diligent reader then begins to look at the text of Article 10(1), she will note that, subject to the critical final phrase of Article 10(1), its effect is to apply Annex 5 - that is, the whole corpus of EU state aid law - to 'the United Kingdom'. Being diligent, she will also note that Article 10 does not (in contrast to, say, Protocol Article 5(3)) restrict itself to 'the United Kingdom in respect of Northern Ireland'; she will therefore

${ }^{5}$ See Chapter 1.

${ }^{6}$ Draft Withdrawal Agreement on the withdrawal of the United Kingdom of Great Britain and Northern Ireland from the European Union and the European Atomic Energy Community (February 2018), https://ec.europa.eu/info/sites/default/files/draft_withdra wal_agreement.pdf.

7 Possible examples will no doubt occur to many readers of this chapter. 
conclude, correctly, that it applies to GB as well as to Northern Ireland. Moreover, by Article 13(3) and (4), future EU legislation (including soft legislation) in the field of state aid will be imported into Annex 5 and will thus have effect in 'the United Kingdom'.

When the diligent reader considers the matter, she will see that that result makes sense, given the EU's concerns as set out above. Northern Ireland is closely integrated economically with GB: the Protocol itself refers to its having an 'integral place in the United Kingdom's internal market'. From the point of view of protecting the EU internal market, it would make little sense to limit the scope of the Article to measures taken by the devolved government of Northern Ireland or to measures benefiting businesses 'based in' Northern Ireland (however those might be defined).

The diligent reader will further note that Protocol Article 12(4) provides that, in relation to Article 10, all the EU's institutions - including the Commission and the CJEU - have the same powers in relation to the UK and persons within it as they do under EU law, and that under Article 12(5) the exercise of those powers has the same legal effects in the UK (all of it) as it does in the EU (a provision translated into domestic law by section 7A of the EU (Withdrawal) Act 2018 (EUWA 2018)). As described above, those powers are very extensive.

At that point, the diligent reader - who, let us assume, is concerned to minimize the extent to which the UK is bound by EU law after Brexit will turn with some anxiety to the wording in the last phrase of Article 10(1) - 'in respect of measures which affect that trade between Northern Ireland and the Union which is subject to this Protocol' - which by this point she will have worked out is the crux of the provision.

There are three concepts in that critical phrase in Article 10(1). The first concept is that of a 'measure', but it fails to confine the application of EU state aid rules at all, since a 'measure' is simply anything to which the state aid rules may apply; it is wording used in Article 108(3) TFEU (which prohibits a member state from putting a 'proposed measure' that falls within the scope of the state aid rules into effect until the Commission has decided whether the measure is compatible with the internal market).

The next concept to consider (in logical order) is the concept of 'that trade between Northern Ireland and the [EU] which is subject to this Protocol'. That raises the question of what trade between Northern Ireland and the EU is subject to the Protocol: to which the answer would appear to lie in those provisions of the Protocol that regulate

${ }^{8}$ Protocol Art 6(2). 
trade between Northern Ireland and the EU. In that regard, one should note Article 5(3) (applying the Union customs code to Northern Ireland), Article 5(5) (applying Articles $30^{9}$ and $110^{10}$ TFEU and prohibiting quantitative restrictions on EU-Northern Ireland imports and exports) and Article 9 (applying EU rules on the wholesale electricity market to Northern Ireland). The upshot is that the trade that is 'subject to the Protocol' is trade in goods and wholesale electricity (covered by the Union customs code and Articles 30 and 110 TFEU, as well as Article 34 TFEU - the prohibition on quantitative restrictions on goods, which also covers electricity ${ }^{11}$ ).

Finally, what does 'affect' mean? It is on the meaning and application of that verb that the bulk of the difficulties and tensions in Article 10 turns. But before considering it, we should look at what happened after the Protocol was concluded.

\subsection{UK Government's Conduct in Relation to Article 10 during the Transition Period}

The implications of the Johnson government's agreement to Article 10 and in particular its potential impact on subsidy control right across the UK - were rapidly picked up by commentators with expertise in the area, including ones generally sympathetic to the Johnson government's aims in the area of subsidy control. ${ }^{12}$ On 3 April 2020, the Chairman of the House of Lords EU Internal Market Sub-committee, which had taken considerable evidence on the issue, wrote to the relevant minister that it was 'troubling that no one we heard from thought that the UK Government had a clear understanding of what state aid provisions it had signed up to in the Protocol, and that the regions and devolved nations we heard from were not clear on how the Protocol might affect them'. She then asked: 'How is the UK Government working now to ensure that the UK-wide implications of the Protocol in a state aid context are fully understood?. ${ }^{13}$ The responding minister failed to

\footnotetext{
${ }^{9}$ Free movement of goods.

${ }^{10}$ Prohibition of discriminatory taxation as between domestic goods and goods produced in other EU member states.

11 See Case C-158/94 Commission v Italy ECLI:EU:C:1997:500, at [17].

12 See James Webber, 'All Change? UK State Aid Law after Brexit: Whose Law? Whose Courts?' https://uksala.org/wp-content/uploads/2020/02/PROOF-COPY-A_New_Subsidy_Control_ Regime_for_the_UK.pdf, pp 12-13.

13 https://uksala.org/wp-content/uploads/2020/04/Level-Playing-Field-and-state-aid-letter -to-BEIS-FINAL-002.pdf, para 56.
} 
grapple with the issue, confining himself to an anodyne reference to meetings of the Joint Committee (JC) ${ }^{14}$

On 9 September 2020, however, it became clear that the Johnson government had indeed taken note of the points being made. As discussed elsewhere in this book, the UK Internal Market Bill published on that day ${ }^{15}$ proposed to give ministers the power to breach the WA by making regulations that would limit the effect and scope of the Protocol in UK domestic law. At the heart of that proposal was clause 43, headed 'Regulations about Article 10 of the Northern Ireland Protocol'. That clause would have given ministers powers to 'interpret' Article 10, or to 'disapply' or 'modify' its effect. These powers were not, as clause 45 made clear, to be limited by any incompatibility with international law (that is to say, including incompatibility with the UK's obligations under the Protocol, agreed by that same government less than a year previously).

To make matters worse, from the EU's point of view, the UK government chose to announce on the same day that it proposed to remove all EU state aid law from the scope of 'retained EU law' (EU law that would continue to have effect, as UK law, after the end of the transition period) and, for the moment, put nothing in its place apart from 'guidance', with a promise to consult later on whether anything further was appropriate. ${ }^{16}$

As related elsewhere in this book, clause 43 and other clauses involving breaches of the Protocol were rejected by the House of Lords and ultimately abandoned. But, as part of the process of that abandonment, the Johnson government negotiated with the EU, in the context of the JC, 'unilateral declarations' on Article 10(1). ${ }^{17}$ The EU declaration (of which a UK declaration 'took note') stated:

When applying Art. 107 TFEU to situations referred to in Art. 10(1) of the Protocol, the European Commission will have due regard to Northern

${ }^{14}$ Letter from Paul Scully MP to Baroness Donaghy of 15 May 2020, https://committees .parliament.uk/publications/1381/documents/12714/default/, p 5.

15 https://publications.parliament.uk/pa/bills/cbill/58-01/0177/20177.pdf.

16 'Government Sets Out Plans for New Approach to Subsidy Control', 9 September 2020, www.gov.uk/government/news/government-sets-out-plans-for-new-approach-to-sub sidy-control.

17 'Unilateral Declarations by the European Union and the United Kingdom of Great Britain and Northern Ireland in the Withdrawal Agreement Joint Committee on Article 10(1) of the Protocol', 17 December 2020, https://assets.publishing.service.gov.uk/government/uploads/ system/uploads/attachment_data/file/946286/Unilateral_declarations_by_the_European_Un ion_and_the_United_Kingdom_of_Great_Britain_and_Northern_Ireland_in_the_Withdra wal_Agreement_Joint_Committee_on_Article_10_1_of_the_Protocol.pdf. 
Ireland's integral place in the United Kingdom's internal market. The European Union underlines that, in any event, an effect on trade between Northern Ireland and the Union which is subject to this Protocol cannot be merely hypothetical, presumed, or without a genuine and direct link to Northern Ireland. It must be established why the measure is liable to have such an effect on trade between Northern Ireland and the Union, based on the real foreseeable effects of the measure.

As will be noted, that declaration concentrated on precisely the term 'affect/ effect' that this chapter earlier identified as the crux issue in determining the scope of Article 10. Its own effect, so far as it has any, is analysed below, but to the extent that anyone may have believed that it represented any common approach between the two sides to the question of how the crux issue of 'effect on trade' should be approached, any such belief could not have survived the competing guidance on that question issued over the following few weeks by the UK government and by the Commission.

Before turning to that issue, however, it is important to note that in the Trade and Cooperation Agreement (TCA), of 24 December 2020, the UK government consented, in Chapter 3 of Part 2, Title XI, to maintain in the UK after the end of transition a domestic subsidy control regime with legal force. However, that agreement left Protocol Article 10 entirely in place.

In June 2021, the UK government introduced a Subsidy Control Bill to Parliament. ${ }^{18}$ That Bill will establish a UK subsidy control regime, the essence of which is the placing of a duty on all granting authorities to grant subsidies only where they are satisfied that 'subsidy control principles' are complied with. Those principles are set out in Schedule 1 to the Bill and are largely drawn from the TCA, with the addition of a principle that subsidies should not distort competition or investment within the UK. The Bill will also prohibit certain kinds of subsidy - essentially those required by the TCA to be prohibited (such as export subsidies, unlimited guarantees, and aid to ailing and insolvent enterprises in the absence of a credible restructuring plan). Compliance with those prohibitions and with duty to apply the principles is secured by a transparency regime (a requirement to put details of all subsidies on a central public database), the possibility (mandatory in some cases) of referring proposed or granted subsidies to the Competition and Markets Authority for a non-binding report, and the right of interested third parties and the UK Secretary of State to challenge any granting decision in judicial review proceedings before the Competition Appeal Tribunal.

18 https://publications.parliament.uk/pa/bills/cbill/58-02/0135/210135.pdf. 
The consequence is that, after transition, the UK now has two entirely separate subsidy control regimes: at present, the one required under the TCA, ${ }^{19}$ to be replaced in due course by the regime set out in the Bill, and Protocol Article 10. The Bill provides that those two regimes are to be mutually exclusive, in that any measure that has been 'given in accordance with Article 10' will be excluded from the UK regime. ${ }^{20}$ In practice, a large proportion of subsidy measures in Northern Ireland will fall under Article 10 and therefore will be excluded from the UK subsidy control regime, but where Article 10 does not apply (for example, in cases where subsidies benefit only services suppliers with no goods element), the UK regime will apply.

\subsection{Crux Issue: Effect on Trade}

The phrase 'so far as it affects trade between Member States' forms part of the definition of state aid in Article 107(1) TFEU. It is frequently described as a 'low threshold', and the point made that, in many cases, what appear to be activities of local interest only have been found to give rise to such an effect. ${ }^{21}$ In Eventech, ${ }^{22}$ the CJEU summarized its case law, stating that 'for the purpose of categorising a national measure as State aid, it is necessary, not to establish that the aid has a real effect on trade between member states and that competition is actually being distorted, but only to examine whether that aid is liable to affect such trade and distort competition'. ${ }^{23}$ It went on to state in particular that 'when aid granted by a Member State strengthens the position of an undertaking compared with other undertakings competing in intra-Community trade, the latter must be regarded as affected by that aid'. It also pointed out that a finding of effect on trade could be made even when the beneficiary of the aid did not itself carry on any intra-Community trade, since the changed pattern of internal trade might affect the ability of suppliers from other member states to penetrate the market. And it

19 The regime required by the TCA forms part of UK domestic law by virtue of section 29 of the EU (Future Relationship) Act 2020, which gives a form of direct effect in UK domestic law to all provisions in the TCA that require domestic implementation. A Subsidy Control Bill was promised in the May 2021 Queen's Speech.

${ }^{20}$ Clause 48(2)(a) of the Bill as introduced.

${ }^{21}$ See, eg, Kelyn Bacon QC, European Law of State Aid, 3rd edn (2017), para 2.153, and the cases there cited.

22 Case C-518/13 Eventech v Parking Adjudicator ECLI:EU:C:2015:9, [2015] 1 WLR 3881, [2015] 2 CMLR 33

23 At paras 65-69. 
emphasized that a finding of effect on trade could be made even if the aid was for a small amount, the beneficiary was small, or the market affected was local in character.

In its subsequent notice on the issue, ${ }^{24}$ the Commission applied that approach to the critical phrase in Article 10(1). On that basis, it noted that aid to an undertaking that sells only a small part of its production in the EU may have an effect on trade. ${ }^{25}$ Combining that point with the point (noted above) that where an aid strengthens the position of an undertaking compared with other undertakings competing in intraCommunity trade, the latter must be regarded as affected by that aid, the Commission concludes that an aid to a company located in Great Britain may 'notably' meet the 'effect' test if that company trades with Northern Ireland. It also states that aid to a services company could indirectly meet the effect on trade test if it indirectly benefits companies engaged in trade in goods or electricity. It concludes with three examples of where the requisite effect on trade would be 'likely': a tax scheme granting a direct or indirect benefit to any firm trading with Northern Ireland; incentives to the financial services industry that would allow manufacturers or electricity companies engaged in trade between Northern Ireland and the EU to access cheaper credit, thus gaining an advantage over their trading partners; and aid to a manufacturer in difficulty if its goods are available for sale in Northern Ireland.

It is evident from those examples that the Commission believes that many UK measures that are focused on GB or are UK-wide would fall within Article 10(1).

In contrast, the UK government's guidance ${ }^{26}$ on the point states that 'the starting assumption for subsidies granted to recipients outside of Northern Ireland should be that the NI Protocol does not apply': and though it recognizes that it could apply where 'a UK-wide measure benefits NI companies' or a subsidy is given to a company with a subsidiary or branch in Northern Ireland, it considers that it would be 'highly unlikely' to apply to a company in GB that exports only to

24 'Notice to Stakeholders: Withdrawal of the United Kingdom and EU Rules in the Field of State Aid', 18 January 2021, https://ec.europa.eu/info/sites/default/files/noticestakeholders-brexit-state-aid_en.pdf.

${ }^{25}$ See Case C-142/87 Belgium v Commission ('Tubemeuse'), ECLI:EU:C:1990:125.

${ }^{26}$ Part 7 of the Department of Business, Energy and Industrial Strategy's 'Technical Guidance on the UK's International Subsidy Control Commitments', 31 December 2020, www.gov.uk/ government/publications/complying-with-the-uks-international-obligations-on-subsidycontrol-guidance-for-public-authorities/technical-guidance-on-the-uks-international-sub sidy-control-commitments. 
Northern Ireland. Further, the guidance also states that there is a 'very strong assumption that aid to services cannot be relevant to Article 10'.

The root of that divergence appears to lie in the UK government's different approach to the December 2020 Declaration from that of the EU. The UK guidance places considerable emphasis on that Declaration. In contrast, the Commission notice states both that the Declaration is 'fully in line' with CJEU case law on 'effect on trade' and that, in any event, it is without prejudice to the CJEU's interpretation of that phrase.

In relation to that difference of view, it is worth noting that (unsurprisingly) nothing in the CJEU's case law expressly allows for a 'hypothetical [or] presumed' effect on trade, or an effect based on anything other than a genuine or direct link to the putatively affected activities. Indeed, it is difficult to imagine that the Commission would ever proceed on a basis that admittedly relied on a hypothetical or presumed effect or on a non-genuine link, or that the CJEU would uphold it if it did. As the Commission notice points out, the effect has to be demonstrated, but the practical point is that the CJEU has accepted as 'demonstration' fairly sparse reasoning that shows only that the measure is 'liable to' affect, rather than that it actually has affected, such trade. It is therefore hard to see that the December 2020 Declaration adds anything to, or subtracts anything from, CJEU case law on the 'effect on trade' in Article 107(1) TFEU (even if the Commission had authority to bind the Court of Justice).

Behind that, however, lies a deeper issue. Is it right to assume that 'affects ... trade' means the same thing in Protocol Article 10(1) as it does in Article 107(1) TFEU? The better view is that it does. Protocol Article $13(2)^{27}$ provides that 'the provisions of this Protocol referring to [EU] law or to concepts or provisions thereof shall in their implementation and application be interpreted in conformity with the relevant case law of the Court of Justice': given the materially identical wording ('affect that trade between'/'affects trade between') in Protocol Article 10(1) and Article 107(1) TFEU, it is hard to resist the proposition that Article 10(1) is here referring to a concept of EU law. Further, that reading of the Protocol reflects the overall approach of the Protocol in applying EU law in full to Northern Ireland in the areas of goods and electricity: it is implausible that such a foundational aspect of single market law was intended to apply in any weaker way than it does in the EU.

${ }^{27}$ See also WA Art 4(3) and (4), although Protocol Art 13(2) goes further by requiring conformity with CJEU case law after the end of the transition period as well as before it. 
All this leaves granting authorities and potential recipients of aid in the UK in a difficult position, if the measure falls into one of the areas where there is divergence between the Commission's approach and that of the UK government. Public authorities must, under section 48(4) of the UK Internal Market Act 2020, 'have regard to' the UK government's guidance in exercising their functions: but that obligation would not extend to following it where the authority considers that it is legally incorrect. ${ }^{28}$ A further, practical difficulty is that if the view is taken that the measure is, or is likely to be, an aid falling under Protocol Article 10(1), and is not covered by an exemption, it follows that it cannot be implemented, or can be implemented only at high risk of a court injunction or a recovery order, unless previously notified to and cleared by the Commission: but such a notification to the Commission may be made only by the UK government, ${ }^{29}$ which is unlikely to do so in a case where its guidance asserts that the measure is not caught by Article 10. In many cases, the parties - and in particular the beneficiary - may well decline to proceed on that basis, or even seek to approach the Commission themselves in order to obtain its view. ${ }^{30}$

\subsection{How Will Disputes Be Resolved?}

One factor that will go into the risk assessment in such cases is that, in practice, it is the Commission's view that is likely to be decisive, subject only to the view of the CJEU. As observed above, the Commission retains, in relation to the UK as a whole, its full panoply of enforcement powers in relation to measures falling under Article 10, including recovery orders and orders to bring the measure to an end (whatever its domestic legal basis). Its decisions can be challenged only in the General Court/CJEU. If

${ }^{28}$ Note that all UK public authorities (not just the UK government) are required by WA Art 5 (and thus by s 7A of the EUWA 2018) to ensure the fulfilment of the obligations arising from the WA and to refrain from any measures that could jeopardize the fulfilment of its objectives. Those obligations would appear to preclude proceeding with a measure that the authority considered to be state aid subject to Art 10, but which is not exempt and has not been notified.

${ }^{29}$ See s 49 of the UK Internal Market Act, as well as the general principle of EU law that only central governments of a member state can make a valid notification: Joined Cases C-442 and 471/03P PઐO European Ferries $v$ Commission [2006] ECR I-4845 at paras 102-07.

30 Such a step would not amount to a notification and could not therefore lead to a Commission clearance decision: but a Commission statement that a proposed measure would in its view be notifiable state aid under Article 10 would at least make it clear to the UK government and the parties that the risks of not notifying were very serious indeed. 
a dispute is raised in a national court, the national court is likely (and on final appeal is bound, subject to the 'acte clair' doctrine) to refer any question as to the meaning of Article 10 to the CJEU. ${ }^{31}$

What if the UK considered that the CJEU had misapplied Article 10 and tried to bring the matter to arbitration under Article $170 \mathrm{WA}$ ? Its difficulty then would be that it would - in order to avoid a reference to the CJEU under Article 174 - have to persuade the arbitration panel that what was at issue was not a 'question of interpretation of a concept of [EU] law': a task that would, for reasons explained above, be difficult to discharge.

\subsection{Conclusion}

As noted in this chapter, one paradoxical result of the way in which the Johnson government handled the negotiation of the WA and the TCA is that, despite its general lack of enthusiasm about scrutiny of its decisions by independent or judicial bodies, it has ended up with not just one subsidy control regime governing its decisions on subsidies but two (the TCA regime, to be replaced by that of the Subsidy Control Bill, and Protocol Article 10). That is not ideal from anyone's point of view (apart from, perhaps, subsidy control lawyers').

There are many examples of issues under the Protocol that could give rise to serious political difficulties. But since disputes over the application of state aid law can affect the legality of critical economic decisions (taxation, rescue of important businesses), the political difficulties that could be caused by differences between the EU and the UK government approaches to Article 10 could well rank among the most serious.

In its July 2021 paper, ${ }^{32}$ the UK government suggested that the subsidy control provisions in the TCA, together with the Subsidy Control Bill, 'provide a more than sufficient basis to guarantee that there will be no significant distortion to goods trade between the UK and [the] EU, whether from Great Britain or Northern Ireland, thus making the

${ }^{31}$ At the time of writing (July 2021) there were ongoing proceedings before the Administrative Court in England and Wales in which British Sugar claimed that a decision by the Secretary of State for International Trade to reduce tariffs on certain imports of sugar by Tate \& Lyle amounted to state aid in breach of Article 10 (as well as a subsidy under the TCA). No decision had been made on the case, or as to a possible reference to the CJEU, as at the time of writing.

32 HM Government, Northern Ireland Protocol: The Way Forward (CP 502). 
existing provisions in Article 10 redundant in their current form' ${ }^{33}$ It went on to offer, on the basis that its proposed replacement for the Protocol was adopted, the possibility of 'enhanced processes for any subsidies on a significant scale relating directly to Northern Ireland for example enhanced referral powers or consultation procedures for subsidies within scope, to enable EU concerns to be properly and swiftly addressed'.

There is some force in the point that, since Article 10 was drafted against a background where the UK might have decided not to have any domestic subsidy control regime at all, its terms should be reconsidered now that the UK is committed to having a domestic subsidy control regime within a framework agreed with the EU. ${ }^{34}$ And, as noted above, it is distinctly unsatisfactory that the $\mathrm{UK}$ is, as a result of Article 10, having to operate two separate subsidy control regimes with an uncertain boundary between them. It is unfortunate that the UK government does not appear to have raised that point during the negotiations leading up to the TCA - which may well be a consequence of its maintaining the position until late in those negotiations that it would not agree to commit to a robust subsidy control regime at all. But the fact that the opportunity to make a fair point was lost at that stage does not mean that the point is not a fair one now, albeit one that may well get lost in the generally combative tone of the July 2021 paper. Unless and until some such arrangement modifying or replacing Article 10 is made, there is a very real danger that it will generate a serious crisis, for example over a Commission or court finding that a politically important UK business tax measure amounted to unlawful state aid under its terms.

33 At para 64.

34 See further George Peretz QC and James Webber, 'The UK's Proposed Revisions to Article 10 of the Northern Ireland Protocol: A Sensible Basis for Negotiation', EU Relations Law, https://eurelationslaw.com/blog/the-uks-proposed-revisions-to-article10-of-the-northern-ireland-protocol-a-sensible-basis-for-negotiation. 